\title{
Making concessions in Tianjin: heterotopia and Italian colonialism in mainland China
}

\author{
MAURIZIO MARINELLI* \\ Centre for East Asian Studies, 8 Woodland Road, University of Bristol, Bristol, \\ BS8 1TN
}

\begin{abstract}
Between 1860 and 1945, the Chinese port city of Tianjin became the site of up to nine foreign-controlled concessions, functioning side by side. Ruth Rogaski has argued that Tianjin's distinctiveness deserves the appellation 'hypercolony', a term which reflects Tianjin's socio-political intricacies and the multiple colonial discourses of power and space. This article focuses on the representations of the ex-Italian concession in Tianjin, a site which is currently renegotiating its identity between reinvention of the past (1901-45) and property-led regeneration. The article employs the concept of heterotopia to explore 'semi-colonial', 'hypercolonial' and 'globalizing' representations of Tianjin's built form.
\end{abstract}

\section{The singularity of Tianjin}

The Chinese port city of Tianjin, between 1860 and 1945, was the site of up to nine foreign-controlled concessions (zujie). ${ }^{1}$ This article focuses on the Italian concession (1901-45) and explores its historical legacy.

Tianjin gained historical significance because of its strategic geopolitical position at the northern terminus of the Grand Canal on the Hai River, and on the Dagu Tianjin-Beijing axis. The city has traditionally been the port of Beijing, $120 \mathrm{~km}$ to the north-west. It was opened as a treaty port in 1860 , when the British, French and American ${ }^{2}$ concessions were established.

In the latter half of the nineteenth century Tianjin became a base for the Westernization movement, and spearheaded the country's transformation of military modernization and societal infrastructure. This process

\footnotetext{
* The research for this article was made possible thanks to a grant from the Universities' China Committee in London and a small research grant awarded by the British Academy. My grateful thanks to the editor Prof. Simon Gunn for his thought-provoking comments and suggestions. The paper has also benefited from advice and insightful comments received from two anonymous peer reviewers.

1 Zujie indicates a part of territory ceded by the Qing Dynasty government to the colonial powers.

2 In 1880, the American concession was absorbed by the British while retaining some residual rights.
} 


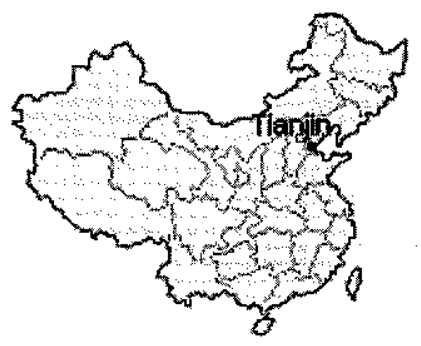

Figure 1: Location of Tianjin

included the construction of railway, ${ }^{3}$ telecommunication, educational and legal systems, and the formation of a mining industry. Tianjin became a major international trading city with shipping connections to all parts of Asia.

Between 1895 and 1902 other concessions were ceded to Japan, Germany and Russia. Even countries that did not yet hold concessions elsewhere in China such as Austria-Hungary, Italy and Belgium all succeeded in establishing self-contained concessions with their own prisons, schools, barracks and hospitals. France, Great Britain and Japan took advantage of the post-Great War situation and enlarged their holdings. The concessions covered an area of 15.5 square kilometres, eight times larger than the old built-up area, and the river front was governed by foreign powers.

It is difficult to find reliable statistics regarding Tianjin's total population: Rasmussen's 1925 account reports that 'In 1860 it was conceded to be about 300,000 ', but this might be inaccurate, due to the citizens' attempt to avoid the heavy taxation system. In 1920 the official figures indicated the presence of ' 837,000 Chinese, 5,914 Europeans and Americans, 4,000 Japanese and 1,200 newly arrived Russians', but Rasmussen doubts the total figure's accuracy $(11,114)$, and suggests approximately 15,000 foreigners (excluding troops) as more realistic. ${ }^{4}$

Concessions in Tianjin were progressively dismantled in the early to mid-twentieth century: German and Austro-Hungarian concessions in 1917, Russian in 1920 and Belgian in 1929. At that point Tianjin had only four concessions remaining: British, French, Japanese and Italian. However by 1930, when Tianjin was placed under the Executive Yuan ${ }^{5}$ of the Guomindang government, the city was the second in China in terms of foreign trade (after Shanghai), and the largest industrial and commercial centre in northern China.

${ }^{3}$ After 1897 the railway network connected the city with Beijing on the one hand and with Shanhaiguan and Manchuria on the other.

4 O.D. Rasmussen, Tientsin: An Illustrated Outline History (Tientsin, 1925), 263.

5 The Guomindang government consisted of five yuan or Councils: Executive, Legislative, Judicial, Examination and Control. 


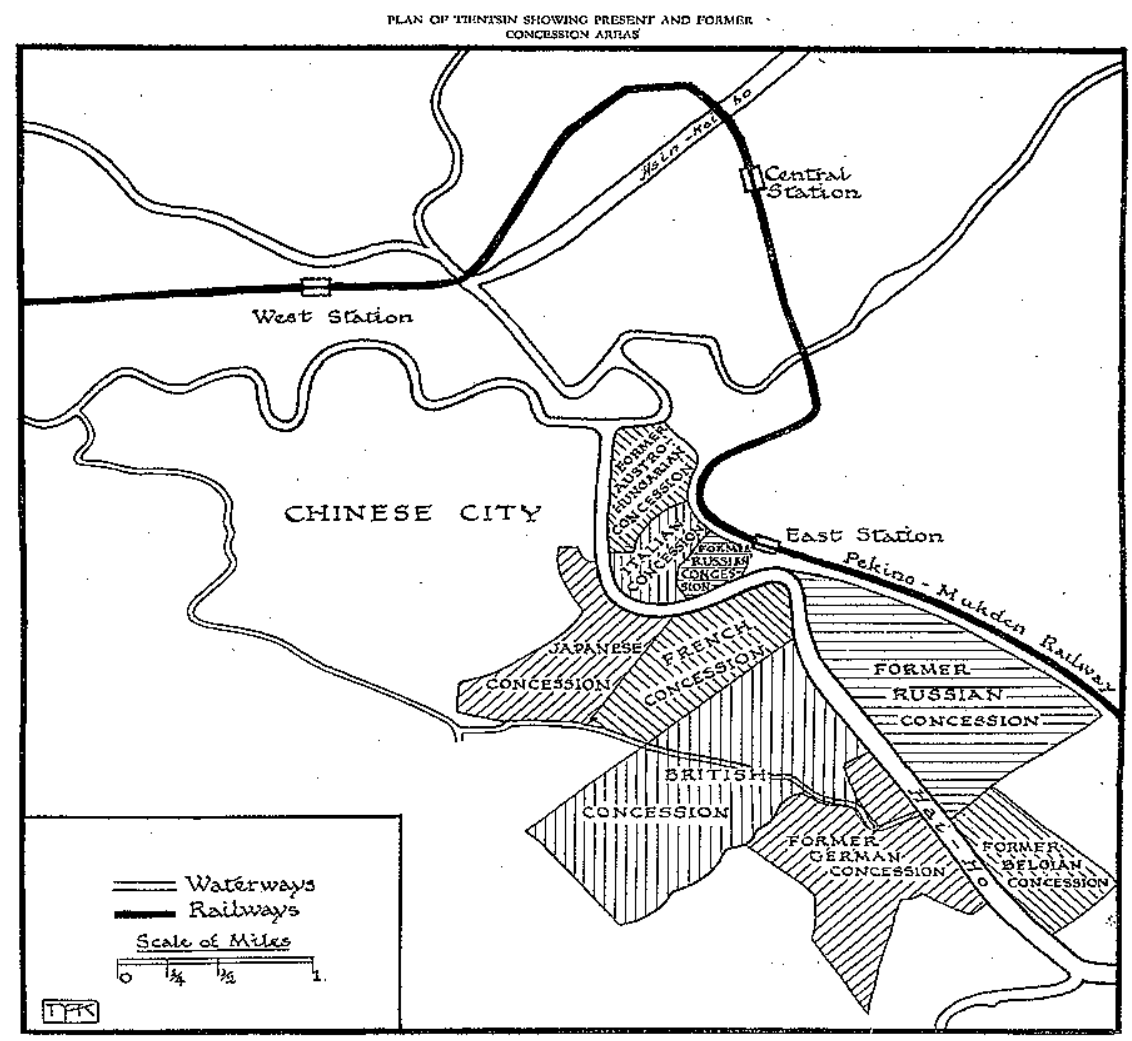

Figure 2: Plan of Tientsin

Source: F.C. Jones, Shanghai and Tientsin (London, 1940).

Captured by Japanese troops on 30 July 1937, Tianjin was occupied until the end of World War II in 1945. At the end of the civil war, Tianjin was liberated by the Red Army in January 1949. After the proclamation of the People's Republic of China on 1 October 1949, all the foreign property in mainland China was seized and nationalized. As Kenneth Lieberthal clearly states:

Tianjin in 1949 was a bifurcated society... Under Western impetus, it gradually developed a modern economic structure that centered in the concession area of the great powers...Still, this modern economic structure did not displace the older society and economy on which it had been built. Rather, the two dimensions of Tianjin existed side by side, partially complementing and partially oblivious of each other. ${ }^{6}$

${ }^{6}$ K.G. Lieberthal, Revolution and Tradition in Tientsin, 1949-1952 (Stanford, 1980), 3. 
There has been a tendency to dismiss or ignore the complexity of Tianjin's multi-layered identity. According to the traditional narrative formulated by Sun Yatsen, ${ }^{7}$ China's condition of semi-colonialism (banzhimindi - as opposed to the hegemony of a single colonial power) was an obstacle to the emergence of indigenous nationalist movements, and the affirmation of native administrative practices. Even in the case of Tianjin, the idea of semi-colonialism is often combined with the idea of the semi-feudal (banfengjian shehui). ${ }^{8}$

Ruth Rogaski, on the contrary, argues that Tianjin's distinctive juxtaposition of many concessions within a single urban space deserves the appellation 'hyper-colony'. ${ }^{9}$ This useful definition contrasts with Sun Yatsen's claim that the incomplete colonization process in China created a 'hypo-colony' (cizhimindi): a weak country which, due to its 'semicolonial' and 'semi-feudal' condition, struggled to find unity, stability and, ultimately, to negotiate its national identity vis-à-vis the foreign powers. Rogaski's image of hyper-colony, 'drawing attention to the potential implications that arise when one urban space is divided among multiple imperialisms ${ }^{\prime}{ }^{10}$ is more in line with the political and cultural intricacies of Tianjin. It indicates the outgrowing evolution of multiple colonial discourses of power and space in the period between 1860 and 1945: these were generated by the intersection and juxtaposition of practices and representations which were both foreign-foreign and foreign-indigenous, as demonstrated by the case of the Italian concession.

\section{The Italian concession}

With the final Protocol of 7 September 1901, following the Boxers' repression,"11 Italy received an allotment of 5.91 per cent of the Boxers' indemnity, extraterritoriality privileges in the Legation Quarter in Beijing, as well as the concession in perpetuity of a small zone (approximately half a square kilometre) $)^{12}$ on the left bank of the Haihe, in Tianjin, on

${ }^{7}$ Sun Yatsen, Guofu Quanji (Taibei, 1961), vol. I, Sanminzhuyi lecture 2:19.

${ }^{8}$ See Tianjinshi zhengxie wenshi ziliao yanjiu weiyuanhui (ed.), Tianjinde yanghang yu maiban (Tianjin, 1987), 1.

9 R. Rogaski, Hygienic Modernity:Meanings of Health and Disease in Treaty-Port China (Berkeley, 2004), 11.

10 Ibid.

11 The Boxers' Rebellion, directed against foreign influence on trade, politics, religion and technology, crumbled on 4 Aug. 1900 when 20,000 foreign troops entered Beijing. See J. Spence, The Search for Modern China (New York, 2001), 232.

12 See G.E. Pistolese, 'La concessione Italiana di Tien-Tsin', in Rassegna Italiana, A. XII, Special Volume (XLI) 'L'Italia e L'Oriente Medio ed Estremo', Aug.-Sep. 1935, 306. De Antonellis reports 447.647 sq. m. In G. De Antonellis, 'L'Italia in Cina nel secolo XX', Mondo Cinese, $19(1977), 52$. A Chinese source indicates an area of '714 $m u, 722 m u^{\prime}$ ( $1 \mathrm{mu}$ corresponds to 0.0667 hectares, therefore, 47.62 ha. or 48.15 ha. respectively), see Li Wenxin, 'Yizujie' (The Italian concession), in Tianjinshi zhengxie wenshi ziliao yanjiu weiyuanhui (ed.), Tianjin zujie (Tianjin's concession) (Tianjin, 1986), 135. Another Chinese source reports the Italian 


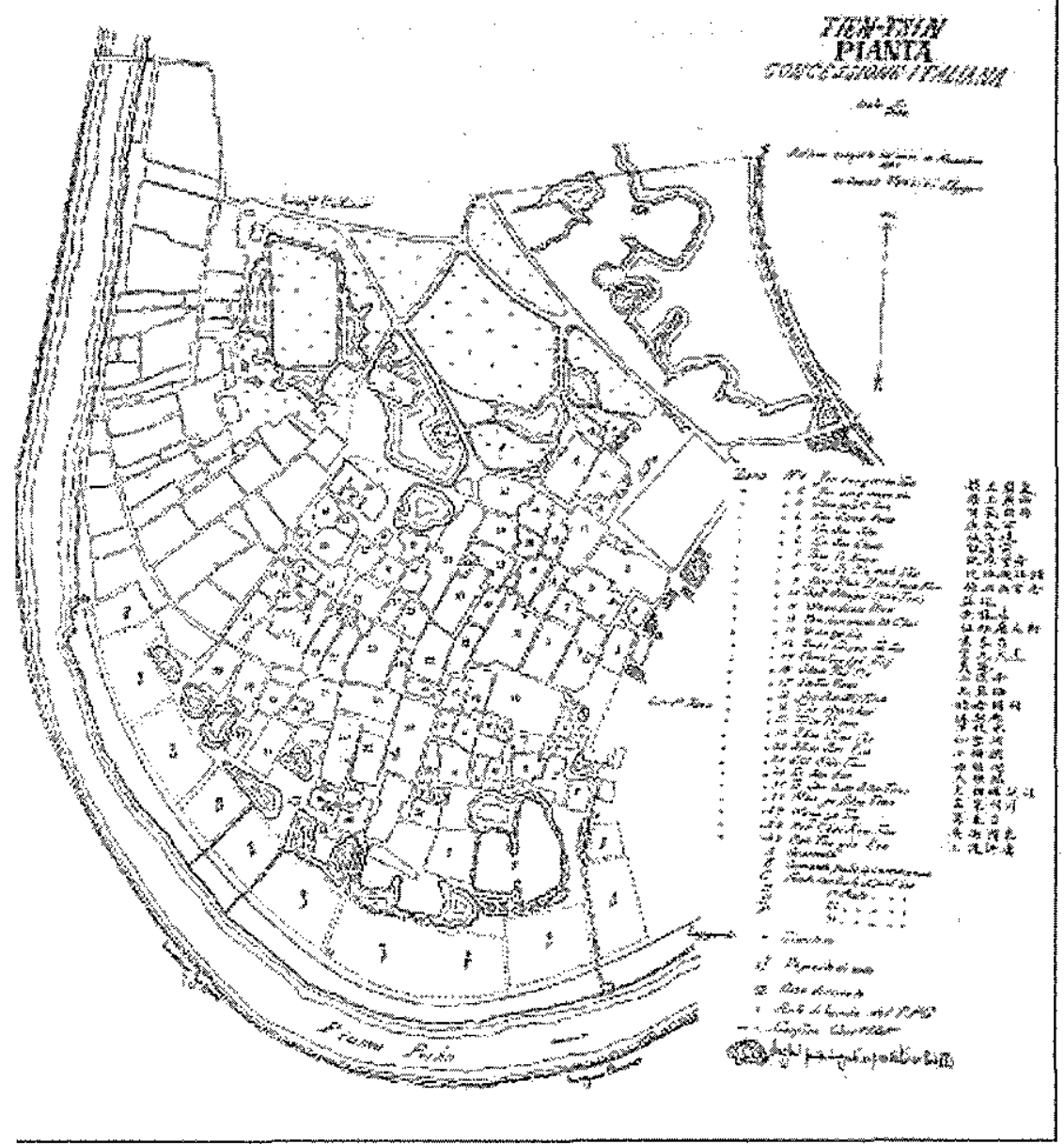

Figure 3: Map drawn in November 1901 by the coastguard Filippo Vanzini

Source: V. Fileti, La concessione italiana di Tien-tsin (Genoa, 1921), 13.

which to develop an Italian concession. Observers, diplomats and scholars in Europe and China have produced over time multiple descriptions of the Italian concession. Cultural-political and socio-economic contingencies have shaped dominant modes of colonial knowledge production and postcolonial derivative discourses. The testing ground chosen in this article is the appropriation of space and its reinvention. 
The built environment of the Italian concession was, in colonial times, and remains today, a political terrain of identity negotiation, which throws 'into relief processes - - historical ones, needless to say - of power'. ${ }^{13}$

Michel Foucault defined his era as 'above all the epoch of space' where the key element is juxtaposition. He coined the term 'heterotopia', which refers to the projective dimensions of near and far, side-by-side and finally the dispersed. He describes our experience of the world using the image of 'a network that connects points and intersects with its own skein'. ${ }^{14}$ This does not dismiss the value of time, but directs the historian's attention towards the often overlooked intersection of time with space, since it is within the conceptualization of space as a social process that strategies of power and signification jointly operate.

An example of juxtaposition of near and far spaces side-by-side can be found in the American journalist John Hersey's representation of the multi-layered identity of colonial Tianjin:

What a weird city I grew up in. For three or four Chinese coppers, I could ride in a rickshaw from my home, in England, to Italy, Germany, Japan, or Belgium. I walked to France for violin lessons; I had to cross the river to get to Russia, and often did, because the Russians had a beautiful wooded park with a lake in it. ${ }^{15}$

The excerpt shows how, to paraphrase Gaston Bachelard: 'It is the pen that dreams. ${ }^{16}$ The crescendo of Hersey's perception of juxtaposed spaces reveals a strong affective conten.t. ${ }^{17}$ Due to an intensely emotional experience, Hersey mirrors the close association between external and internal spaces. Yet the countries mentioned here do not embody the physicality of nationally defined geographical spaces, they indicate instead the adolescent Hersey's subjective representation of the 'Disneyland-style' reproduction of the world within the space of Tianjin's concessions area. This physical space assumes the connotation of a multi-layered emotional space.

As Foucault says, drawing upon Bachelard's epistemology: 'The space of our primary perception, the space of our dreams and that of our passions hold within themselves qualities that seem intrinsic. ${ }^{\prime 18}$ These intrinsic qualities derive from emotional dispositions, which determine

13 M. Foucault, Power/Knowledge: Selected Interviews \& Other Writings 1972-1977, ed. Colin Gordon (New York, 1980), 149.

${ }^{14}$ M. Foucault, 'Des espaces autres', Architecture, Mouvement, Continuité, 5 (1984), 46-9; also available in M. Foucault, Dits et écrits 1954-1988, vol. IV: 1980-1988 (Paris, 1994), 752-62. For this quote see 46.

15 J.R. Hersey, 'A reporter at large: homecoming. I: the house on New China Road', New Yorker, 10 May 1982, 54. Hersey (1914-93) was born in Tianjin to missionary parents. His family returned to the States when he was ten years old, but in 1939 he went back to China as a reporter for Time.

16 G. Bachelard, La poétique de la reverie (The Poetics of Reveries) (Boston, MA, 1992), 6.

17 A. Ortony, G. Clore and M. Foss, 'The referential structure of the affective lexicon', Cognitive Science, 11 (1987) 341-64; A. Ortony, G. Clore and A. Collins, The Cognitive Structure of Emotions (Cambridge, 1988).

18 Foucault, 'Des espaces autres', 46. 
the emergence of emotional representations from apparently objective descriptions. The action of crossing the Haihe to get to the Russian concession evokes a mythical and psychological journey. Hersey's mention of the 'beautiful wooded park' and his following remark 'I hold in my nostrils to this day the strange odour of tadpoles captured in Russian waters and taken back to England ${ }^{\prime 19}$ allude across time and space to a whole range of bodily sensations. These push him to test the limit of an implicit synaesthetic experience, where all his senses seem to intermingle in a sort of Proustian awakening upon tasting the petit madeleine. Growing up in Tianjin was characterized by experiences that signified an epoch of juxtaposition, both in terms of physical and emotional space.

\section{The real and the unreal}

In the case of the Italian concession, an in-depth documentary analysis reveals the progressive construction of a collective emotional space. This space is inhabited and shared by the Italian colonial agents, and conditions and informs all of their individual representations.

Emotions are not only individual forms of psychological activity; they can reflect the formation of a collective mindset and contribute to its survival. Therefore, emotions can play a significant role in the consolidation of a patriotic ideology: they contribute to guarantee the stability of the leading group and maintain the relevant social order. In this case a more socially and politically useful mode of expression is needed: a structure can be created through the media or country reports, which is strong enough to convey the general feelings in a certain direct way and somehow restrict and harness individual emotions. This structure, which is an important component of the habitus ${ }^{20}$ of colonial agency, can be defined as collective emotional capital: the emotional capital is itself a structuring structure, a practice-unifying and practice-generating principle, which is powerful and employable at different times in history. One that is constructed through a system of practical knowledge that creates the tendency, in the colonial agents, to perceive the colonial subject and appropriate its space with a certain 'naturalness' within a specific ideological universe. Therefore, the collective emotional capital constructs a subjective space: since it is both an inhabited form of thinking and a unifying way of seeing. This is meant to regulate and restrict the emergence of other forms in situ (i.e. in the concession itself), as well as ensuring that the collectivity in the motherland is familiar with a specific version of reality.

19 Hersey, 'A reporter at large', 54.

20 Habitus refers to a system of practical knowledge, acquired over time, which creates in the social agents the tendency to perceive, act and react with a certain naturalness within a specific social universe, without any need to be coordinated or governed by rules. See P. Bourdieu, Distinction: A Social Critique of the Judgment of Taste (London, 1984). 
The concessions area in Tianjin is a paradigmatic juxtaposition of the 'absolutely real' with the 'absolutely unreal': it is created through the convex-mirror mechanism of reflection, distorted perception and projective duplication. ${ }^{21}$ It was not a utopia, since it was not an unreal space ideally constructed as a perfect analogical projection of an existing society. Both in terms of physical and emotional construction, the concessions area can be defined as a multi-layered heterotopic site since, de facto, the concessions, via translingual practice, ${ }^{22}$ fall into the Foucauldian category of 'real places... which are something like counter-sites, a kind of effectively enacted utopia, in which the real sites, all the other real sites that can be found within the culture, are simultaneously represented, contested and inverted'. ${ }^{23}$ The topography of the newly created Italian concession can be compared to various towns which were designed, built and inaugurated in Italy during the fascist period. In the years 1928-34, the towns of Littoria, Pontinia and Sabaudia emerged on the reclaimed Agro-Pontine marshland, not far from the capital Rome. The coastal town of Sabaudia, in particular, is the alter ego of the Italian concession in Tianjin. Its construction began on 5 October 1933 and took only 253 days; it was based on the Roman grid road layout, with the typical main square connecting the radiating streets, and characterized by rationalist-fascist architecture.

In Tianjin, each colonial power proceeded to annihilate the previous spatial organization of the site and completely reinvented the physical space of the territory under its control. By employing imported urban planning criteria, building regulations and architectural styles, each country reflected its own national tradition and produced miniature representations of the imagined motherland. Although, at times, the concessions revealed a partial absorption of influences that derived from neighbouring ones. The once-massive city walls ${ }^{24}$ paved the way to the emergence of neighbourhood enclaves that displayed a built form reminiscent of Brooklyn brownstones, Bavarian castles, Italian squares with fountains and Parisian cafes. The strategic commitment to create the 'real' within the other space ended up intertwining with the 'unreal' in forms and processes dominated by mimicry and hyper-simulation. ${ }^{25}$ Each concession included a residential area, which responded exclusively to the objective requirements and subjective expectations of the expatriates of the colonial power. Thus each concession became a lifestyle showcase of

${ }^{21}$ See M. Marinelli, 'Self-portrait in a convex mirror: colonial Italy reflects on Tianjin (19011947)', Transtext(e)s-Transcultures, 3 (2007), 119-50.

22 I borrow this definition from Lydia Liu, who uses it to refer to the necessity to reinvent the meaning of words in a different context. L. Liu, Translingual Practice: Literature, National Culture and Translated Modernity China 1900-1937 (Stanford, 1995), 24.

${ }^{23}$ Foucault, 'Des espaces autres', 47.

24 See Yunjing Guo (ed.), Tianjin gudai chengshi fazhan shi (History of the development of the ancient city of Tianjin) (Tianjin, 1989).

25 On simulation see Jean Baudrillard, 'Simulacra and simulations', in J. Baudrillard, Selected Writings, ed. Mark Poster (Stanford, 1988), 166-84. 
the respective colonial power, while each colonial power avowedly used its concession site to organize, promote and expand the commercial activities of the firms of its own nationality.

\section{Internal and external space}

The Italian concession was simultaneously a sort of mythic and real contestation of the space in which the colonial agents lived. Consul General Vincenzo Fileti, in his 1921 report, insists on depicting the Chinese as diffident and resistant (i.e. unwilling to abandon their 'rigid obstinacy'), ${ }^{26}$ and even ignorant and superstitious, belonging to a closed civilization jealous of its own ideology:27

Inside the Great Wall, the Chinese people continue to live with their own peculiar habits and customs, which are so profoundly different from ours, and with their own mentality, which is insensitive to any western innovation; the Chinese people are satisfied with their own condition, and jealous of their own ideology, which they consider much superior to the western one. ${ }^{28}$

The lexicon of this excerpt contributes to build that emotional capital necessary for the colonial agent to proclaim the superiority of its own civilization, therefore, justifying the legitimacy of its own actions, practices and relevant representations. Fileti's agenda becomes self-evident when he stresses his vision regarding China as a land of exploitation, ${ }^{29}$ and the allegedly logical necessity for Italy not to miss the opportunity to exploit this land:

Today the European and American capitals, and for the most part Italian labour, have succeeded in building there about 3,500 miles of railways, a very small figure considering the total surface of China ... It is therefore a vast virgin land for economic exploitation that can be opened to human activity and the effort to overcome the difficulties is well justified ... all the nations that feel strength, due to their commercial and ind ustrial development, have always looked with active and growing interest to the vast and virgin Chinese market and seized every favourable opportunity to breach the wall enclosing such a treasure, to avoid being second or overpowered in the exploitation of that vast new market. ${ }^{30}$

The idea of 'catching up' and accelerating the process of conquest and exploitation - to compensate for Italy's late arrival on the global

26 V. Fileti, La concessione italiana di Tien-tsin (Genoa, 1921), 8.

${ }^{27}$ I think of ideology here in Clifford Geertz's sense: as a cultural system. See C. Geertz, Interpretation of Cultures (New York, 2000). Geertz also argues that nationalism is an emotional ideology: see C. Geertz, Proud to be who I am', 16 Apr. 2007, www.geertzian.org $/ ? \mathrm{p}=189$, accessed 3 May 2007.

28 Fileti, La concessione, 8 .

29 The classic image of China as a golden, nearly boundless market for European manufacturers might be derived from Adam Smith. See A. Smith, An Inquiry into the Nature and Causes of the Wealth of Nations, 1776, online version, Book I, www.adamsmith. org/smith/won/won-b1-c11-digressions-3.html, accessed 12 Jul. 2007.

${ }^{30}$ Fileti, La concessione, 8-9. 
imperialistic arena - dominates Italian colonial literature. However, it is carefully and strategically concealed under the hagiographic picture of the Italian mission civilisatrice. ${ }^{31}$ This rhetorical trope was based on the 1890s claim that 'Italy's was a "proletarian" colonialism' and therefore less pernicious than the others, since it would have been 'aimed to secure better land and greater prosperity for its indigenous citizens' ${ }^{32}$

Fileti's report reveals the juxtaposition of external and internal space: the external indicates the self-positioning of Italy as a colonial nation, both within Tianjin and, more significantly, within the international community, while the internal space is the subjective position of the state representative as consul general in Tianjin. The external space is imbued with quantitative elements, which allude to the various possibilities of economic exploitation, in consideration of the vastness of the indigenous territory, but also in comparison with other foreign powers; the internal place is tinged with emotional qualities such as pride, greed and arrogance. The hagiographic description of the sanitization process and urban modernization of the concession's territory reveals the symbiotic relation between national and individual pride. This also constructs the metanarrative $^{33}$ of magnanimous salvation of the Chinese space, and allegedly the Chinese people, ${ }^{34}$ from misery, poverty and indigence, ${ }^{35}$ no doubt thanks to its annihilation and the consequent replacement with the insignia of 'progress and modernity', characteristics of the colonial nation.

Since the acquisition in 1901, every unilateral action was legitimate. After signing the agreement with the director of the Chinese Maritime Customs Tang Shaoyi, Ambassador Giovanni Gallina justified the immediate expropriation of the 'filthy Chinese village', arguing that 'all the other powers proceeded to the expropriation as soon as they occupied the area of their concession'. ${ }^{36}$ The agreement clearly stated that the concession was

31 See A. Aruffo, Storia del Colonialismo Italiano: da Crispi a Mussolini (Rome, 2003), 23-46. See also A. Del Boca, Italiani Brava Gente? (Vicenza, 2005).

32 J. Andall and D. Duncan, 'Memories and legacies of Italian colonialism', in J. Andall and D. Duncan (eds.), Italian Colonialism. Legacy and Memory (Oxford, 2005), 11. See also R. Ben-Ghiat and M. Fuller (eds.), Italian Colonialism (London, 2005).

33 In the sense of a totalizing cultural narrative schema which explains both the claimed knowledge and its relevant experience.

34 According to the 1902 census, 13,704 people lived in the concession (17,000 according to Fileti's report, 16,500 according to Arnaldo Cicchiti-Suriani). According to a Chinese source, based on the 1922 census, the total population was 4,129 including 4,025 Chinese, 62 Italians and 42 from other nationalities. See Nankai daxue zhengzhi xuehui (ed.), Tianjin zujie ji tequ (Tianjin's concessions and special areas), Shizhengfu congshu series (Tianjin, 1926), 6-7; A. Cicchiti-Suriani, 'La concessione italiana di Tient Tsin (1901-1951)', Rassegna Italiana di Politica e Cultura, 31 (1951), 563.

35 Fileti, La concessione, 14-15.

36 Ministero Affari Esteri, Direzione Generale Affari Commerciali, 'Concessione italiana di Tien Tsin, Pro Memoria', in ASMAE (Archivio Storico del Ministero degli Affari Esteri), Serie $P$, pos. $86 / 37$, pac. $429(1912-14)$. 
ceded 'to promote the development of Italian trade in the northern part of China, and in the Zheli (Chi-li) province in particular' ${ }^{37}$

The emotional space of the colonial power is a heterogeneous space since the colonial agents do not operate in a vacuum where they can place themselves ad libitum. Rather it is an ideologically constructed universe, which requires its agents to act according to precise mechanisms of power/truth: they live inside a set of relations with the motherland and the other foreign powers, and these are relations of power that delineate sites that are irreducible to one another and absolutely not superimposable on one another'. ${ }^{38}$

The emotional space is determined both by the subjective sense of belonging to a precise nation and by the objective co-presence with the other foreign concessions. The concession's space can be seen as heterotopia exactly because it 'has the curious property of being in relation with all the other sites', ${ }^{39}$ creating a dialectic set of relations dominated by mechanisms of affirmation, reflection and self-reflection, which are in the end mechanisms of power.

\section{The function of the concession and its built form}

Hyper-colonial Tianjin, with its concessions area, played a crucial international function as the major entrepôt to enable foreign-foreign trade between the various colonial powers and promote foreign-indigenous commerce, especially with the northern part of China.

The industrial, banking and maritime customs system developed in Tianjin after 1860 revealed, both materially and figuratively, an awareness of the importance of knowing what relations take form among sites.

The concessions were de iure and de facto special physical spaces, but arguably also emotional spaces, due to the enjoyment of unique rights. The juridical power of the nation of origin was extended to its citizens living abroad, who enjoyed the principle of extraterritoriality and were exempted from Chinese laws. ${ }^{40}$ One could argue that 'hyper-colonial' Tianjin was a utopia, but utopia is an unreal space, a site with no real place, which presents society in a perfected form. Utopias have a consoling function, while heterotopias are unsettling: they unmask the radical alterity without assuming a possible conciliatory solution. The application of the principle of extraterritoriality is evidence of the imperfection and lack of any possible conciliation of the concessions area.

From 1860 to 1901, physical alterity emerged in Tianjin. The various techniques of spatial appropriation determined the dissolution of the

${ }^{37}$ Agreement. Italian text.

38 Foucault, 'Des espaces autres', 47.

39 lbid.

40 Extraterritoriality was first imposed on China with the Anglo-Chinese Treaty of Nanjing (29 Aug. 1842), at the end of the first Opium War, and later extended to citizens of other nations. 
traditional hierarchical ensemble of places: the ordered and almost geometrical identitary form, which is one of the main characteristics of the walled configuration of traditional Chinese cities, disappeared. A systematic desanctification of space occurred, for example, in the Italian concession, where the cemetery was removed, the wetland reclaimed and the process of urban regeneration imposed Italian names to the streets; while the building code set the rules and regulations for the layout of Western-style roads. ${ }^{41}$ These included maximum two-storey high foreignstyle buildings, and 'European style, elegant residences'. The building regulations associated class status and moral behavioural patterns: 'All the buildings facing the Vittorio Emanuele road must be in European style and exclusively occupied by Europeans of good character and standing, or by Daotais or other high Chinese officials who must obtain a permit from the Royal Italian Consulate. ${ }^{\prime 42}$

The buildings had to respect the foreign or semi-foreign style, and only the consul had 'full power to order any alteration of any building not put up in accordance with the plan rendered to him for sanction; or order any repair with regard to safety and hygiene ${ }^{\prime} .{ }^{43} \mathrm{He}$ also had full power to issue the order to pull down any building which was not strictly in accordance with the building regulations. ${ }^{44}$

The building code shows a pervasive association between ethnicity, morality and hygienic modernity: 'Chinese inhabitants on the unexpropriated portion of the concession' must keep their houses clean, including 'the portion of the road in front of their houses' (XXIV, 1). Moreover, 'All kinds of public entertainments must be authorized by the police' (XXIV, 13), while a special permission is required to open Chinese theatres and the proprietors must 'guarantee the morality of the artists as well as the public safety' (XXIII). Chinese inhabitants had to obtain approval 'previous to weddings, funerals or any other function' (XXIV, 10). The discriminatory rule establishing that 'Any native of bad character may be expelled from the concession' (XXIV, 13), indicates a high level of discretion in the binary of 'good' and 'bad'.

The style of the buildings mostly reflected the widespread appreciation and diffusion of neo-Renaissance palazzos in nineteenth-century Europe. ${ }^{45}$ This architecture was exported from the Italian motherland to various

41 Royal Italian Concession in Tientsin. Local Land Regulations and General Rules, Building Regulations.

42 Ibid., 2, article I. Daotai refers to an official at the head of the civil and military affairs of a circuit, which consists of two or more or territorial departments (fu). A possible translation is 'Intendant of circuit'. Foreign consuls and commissioners associated with Daotai as superintendents of trade at the treaty ports are ranked with the Daotai.

43 Ibid.

44 Ibid., 2, articles III, XI.

45 In England, the equivalent of this style is the so-called 'Renaissance Italian palazzo', inspired by John Ruskin's panegyrics to the architectural wonders of Venice and Florence around 1840. See R. Pavoni, Reviving the Renaissance: The Use and Abuse of the Past in Nineteenth-Century Italian Art (Cambridge, 1997), 73. 


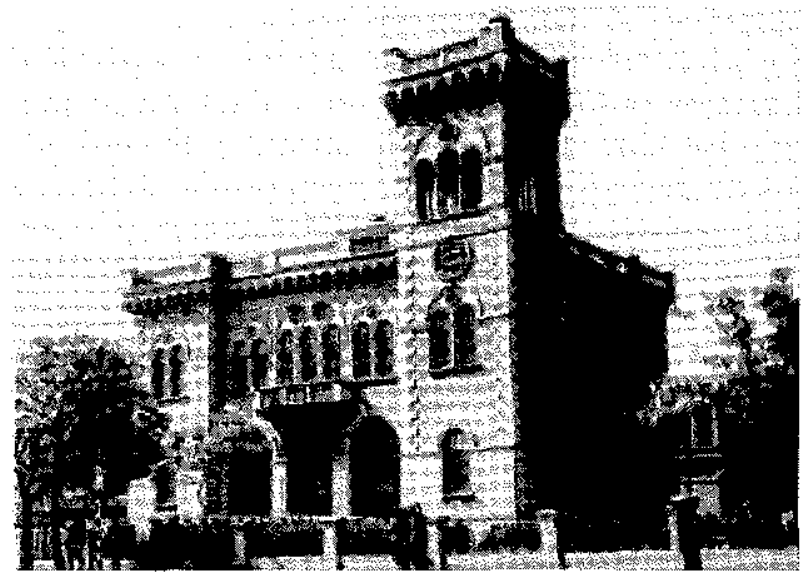

Figure 4: Italian Council (gongbuju)

Source: photograph from the Historical Archives of the Italian Foreign Ministry in Rome.

European countries and then to China. This built form is continuously mentioned in the Italian colonial literature. ${ }^{46}$ The concession assumed 'the role of showcase of Italian art, with the import of decorating and building materials from the motherland', especially for 'the most representative objects, like the public buildings and the monumental fountain located at the centre for Piazza Regina Elena' ${ }^{47}$ Neo-Renaissance architecture is a paradigmatic signifier of emotional capital indicative of the colonial mindset. Its imposition in Tianjin reflected the semantics of colonial power: the affirmation, via universalization, of national pride and prestige by means of the constructed form. The 'villino' hosting the Italian Council is the most emblematic example. It designated a precise spatial identity, and enforced a national discourse of power within the hyper-colonial space of Tianjin, while also projecting that kind of discourse on to the motherland. It was built by the company belonging to the long-time Tianjin resident Egidio Marzoli, and clearly echoed fifteenth-century Italian villas, characterized by a square shape, consistent floor plan and a hipped-roof surmounted by a turret. This building symbolized the affirmation of Italian political and emotional capital in Tianjin. ${ }^{48}$

46 R.L. Borgnino, 'La "concessione" Italiana in Cina', Augustea (1936), 363-6. Nicoletta Cardano and Pier Luigi Porzio (eds.), Sulla via di Tianjin: mille anni di relazioni tra Italia $e$ Cina. Un quartiere Italiano in Cina (Rome, 2004), 44-5.

47 Cardano and Porzio (eds.), Sulla via di Tianjin, 34.

48 In 1925, the architect Bonetti, a resident of the concession, drew up a plan to expand the building, by means of a heated veranda to be used as a reception room. This building was destroyed around 1990. 
In the appropriative colonial space, the notion of 'neo' is particularly significant, since what collectively goes under the name of 'neo' is often a cannibalized version of the past, reflected in the form of architectural pastiche through the reinvention of dead styles. To the eye of a careful viewer, the superimposition of foreign architectural styles reveals the 'Disneyland-style' miniature of the world that foreign powers tried to affirm as a regime of power and truth in hyper-colonial Tianjin. But the concept of the city as a 'space of emplacement' was disrupted by the division between the Chinese city and the foreign concessions area on the one hand, and the progressive fragmentation, integration and ultimately disappearance of the various concessions, in the early to midtwentieth century, on the other.

\section{The past in the present}

Today, the Tianjin municipal government considers the 'semi-colonial' historical conjuncture as the beginning of the 'opening up' and 'globalization' of Tianjin. The past is transmogrified in a new teleological version and is now represented as a catalyst for the providential transformation of Tianjin from a static and finite place to a dynamic and open space. Forms and practices from the past are redeployed and reinvented in the present. The rhetoric of Tianjin's collective emotional capital today reflects a shift from the pre-1980s emphasis on place localization and the necessity to safeguard national sovereignty against imperialistic aggression, towards the politics of place competition at the national and international level. ${ }^{49}$ A narrative of space extension, internationalization and globalization has progressively emerged at the turn of the twenty-first century. ${ }^{50}$ This leads to a selective re-writing of the past, where the rhetorical trope of the Italian 'aristocratic concession' becomes particularly useful.

Frances Wood informs us that in many of the treaty ports 'foreigners lived outside concession areas altogether or at least outside their own country's concession' ${ }^{51}$ British journalist H.G.W. Woodhead, in 1934,

49 See for example: Xiao Huaiyuan (ed.), Tianjin 2006 Basic Facts (Beijing, 2006), along with the videos 'Tianjin, a fascinating city' (Meili Tianjin) and 'Tianjin Binhai new area - an important power invigorating regional development' (Tianjin Binhai xinqu-daidong quyu fazhande zhongyao liliang) both compiled by the Propaganda Department, Tianjin Municipal Party Committee, Tianjin Municipal Information office, Tianjin Television Station, 2006.

50 This is a general trend, as demonstrated also by the television series Daguo jueqi (The Rise of Great Nations), shown on China's state network CCTV across twelve episodes on 13-24 Nov. 2006. There seems to be a widespread tendency to rewrite history: moving away from the previous emphasis on the condemnation of the 'imperialist sin' of the past, when the foreign powers aimed at 'getting rich from the blood of others', the argument now is a more positive appraisal of national experiences, in an attempt to represent the imperialist $\sin ^{\prime}$ of the past as a driving force and a sine qua non for the rise of nations to global status.

51 F. Wood, No Dogs and Not Many Chinese: Treaty Port Life in China, 1843-1943 (London, 1998), 185. 


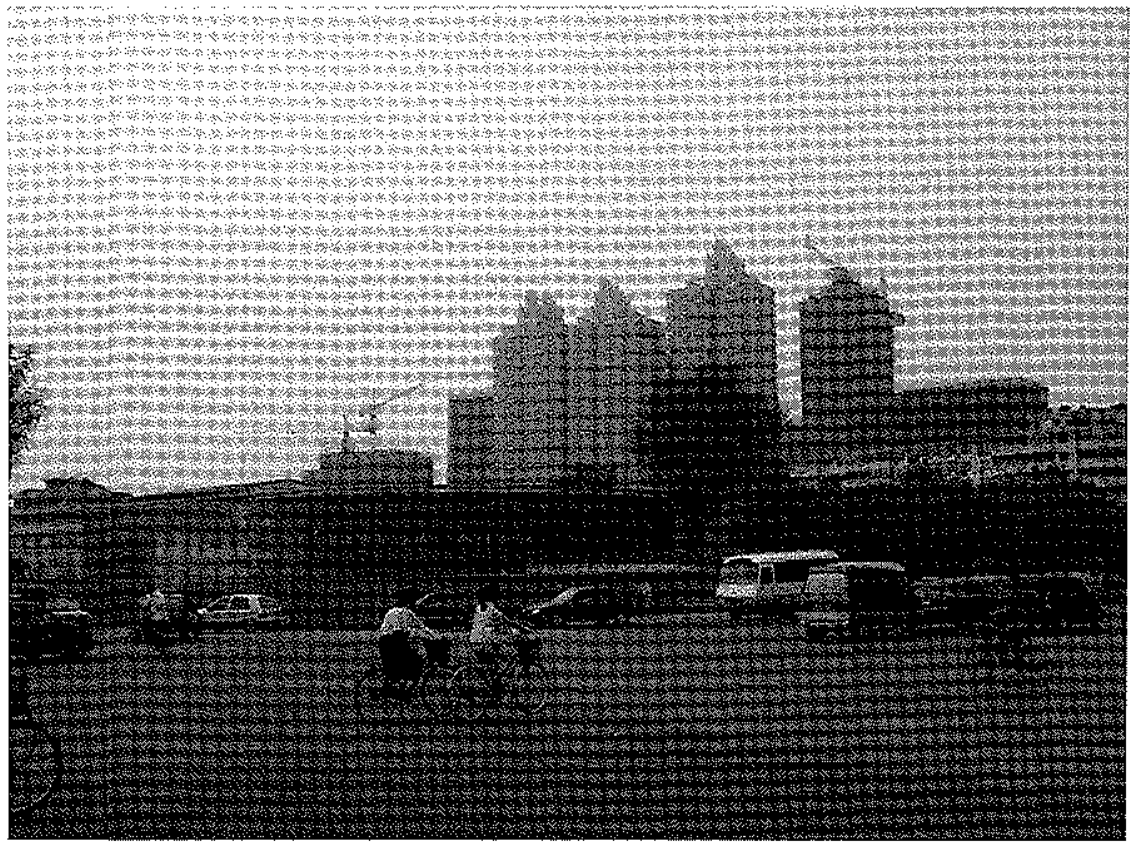

Figure 5: The Chinese slogan says: 'Yesterday's extraordinary blood lineage will be[come] today's broad road (along) the Haihe [the Way to a bright future].'

Source: personal photograph, June 2006.

stated: 'The German concession... was the most favoured residential area for foreigners of all nationalities... The British concession and extension contained the most important foreign banks, offices and shops, and a considerable Chinese population... The Italian concession... was becoming the most popular centre for the palatial residences of retired Chinese militaries and politicians. ${ }^{\prime 52}$

Many sources describe the Italian concession as the aristocratic concession'. ${ }^{53}$ Chinese sources ${ }^{54}$ emphasize how high-ranking Chinese citizens and overseas Chinese, returning after the foundation of the Republic, wanted to reside in the Italian concession. Among them: political theorist Liang Qichao, Tianjin mayors Zhang Tinge, Cheng Ke and Zhou Longguang, journalist Liu Ranggong, playwright Cao Yu, calligrapher Hua Shikui, the infamous 1923-24 'bribing president' Cao Kun, warlord general Tang Yulin, 1921 Minister of Interior Qi Yaoshan, military and civil governor of Heilongiiang Bao Guiqin and wealthy silk businessman Meng

52 H.G.W. Woodhead, A Journalist in China (London, 1934), 65.

53 Borgnino, 'La "concessione"'; Pistolese, 'La concessione', 306.

54 Shan Keqiang and Liu Haiyan, Tianjin: Zujie shehui yanjiu (Tianjin, 1996), 98. 
Yangxuan. ${ }^{55}$ These residents, together with the Italian-style architecture, projected the image of an 'aristocratic' enclave.

\section{Inclusion and exclusion}

In 1985, in his comparative study of Cape Town and Tianjin, geographer John Weston pointed out that 'It did prove somewhat disconcerting on a first visit to a Chinese city to encounter architecture reminiscent of inner Paris, suburban Surrey, or baroque Salzburg in the former concession areas. ${ }^{\prime 56}$ But both in the literature of Italian colonial period ${ }^{57}$ and even today, the sense of being 'disconcerted' is totally neglected and replaced by an assertive narcissism.

The concessions reveal an. element of heterocronies, since they can be considered like museums but living ones. Museification was a crucial process in the appropriation of the indigenous space. This responds to the nineteenth-century notion of modernity: 'accumulating everything, all epochs, all forms, all tastes, the idea of constituting a place of all times that is itself outside the time and inaccessible to its ravages, the project of organizing in this way a sort of perpetual and indefinite accumulation of time in an immobile place'. ${ }^{58}$ But neither the whole concessions ${ }^{\prime}$ area nor the individual concessions were immobile places. They presupposed a mechanism of opening and closing, which both isolated them and made them penetrable. Chinese historians emphasize that, from an administrative, juridical, police and fiscal perspective, the concessions were 'states within the state' (guozhongzhiguo). ${ }^{59}$ However, the Western sources have overlooked this specific feature, and tried to de-emphasize the colonial nature of the concessions' space. The Western terminology ranges from 'quarter' to 'neighbourhood'. In Chinese, the character is ' $\mathrm{qu}^{\prime}$ ', 60 which is literally translatable with the neutrally connotative term 'area'. ${ }^{61}$ Nevertheless, it is undeniable that the concessions were not freely accessible 'areas'. As demonstrated by the building code and extraterritoriality, even when it was possible to enter, there was a permanent element either of inclusion or exclusion.

${ }^{55} \mathrm{Li}$, 'Yizujie', 137-8. The number of Italian residents was always extremely limited. Pistolese argues that, according to more recent estimates, the Italian community in Tianjin would have consisted of about 150 people, instead of 392, even though he paradoxically tries to emphasise how 'Our concession has a demographic consistency superior to the other concessions in Tien-Tsin.' See Pistolese, 'La concessione', 306. According to a Chinese source, based on the 1922 census, 4,025 Chinese citizens, 62 Italians and 42 from other nationalities were living in the concession at the time; see Nankai daxue (ed.), Tianjin, 6-7.

56 J. Weston, 'Undoing the colonial city?' Geographical Review, 75, 3 (1985), 341. Italics added.

57 See Pistolese, 'La concessione', 305-10. See also U. Bassi, Italia e Cina: cenni storici sui rapporti

58 Ibid.

59 Shan and Liu, Tianjin, 1.

${ }^{60}$ Cardano and Porzio (eds.), Sulla via di Tianjin.

61 See Marinelli, 'Self-portrait', 27. 
The fundamental criteria for exclusion were an integral part of nineteenth-century ideas of modernity: (1) appropriation and christening of the urban form; (2) sanitization.

The explicit and implicit values dominating the Italian colonial discourse were unmasked through the new street names. For example, the decision to name the road where the barracks dedicated to national 'hero' Ermanno Carlotto $^{62}$ were located after the sixteenth-century Jesuit and cultural intermediary Matteo Ricci ${ }^{63}$ reveals the intention of the presiding Italian colonial government to utilize historical precedents. Claiming the existence of a long-term relationship between Italy and China simultaneously strengthened the patriotic value of spatial reproduction.

The process of physical demolition or rehabilitation, and ultimately historical and political reappropriation of the colonial buildings after 1949, is particularly significant in the case of Tianjin, as demonstrated also by the renaming of the streets in the concessions area. Following the creation of 'new China', Via Matteo Ricci became Guangmingdao: the Road of Light. Today, some of the most interesting buildings from the concessions' era are located on what was renamed as Jiefangbeilu (North Liberation Road), which runs parallel to the Haihe. Some of the most interesting Italianstyle villas from the period 1908-16 are located in what were renamed Minzulu (National Road) and Ziyoudao (Freedom Road). According to the new geography of space, today the former Italian concession is enclosed between Bei'andao (Northern Peace Road) and Ziyoudao (Freedom Road) on the north, the Haihe on the south, Wujinglu (Five Elements Street) on the east and Xinglongjie (Flourishing Street) and Jianguodao (National Foundation Street) on the north-east. These names indicate the reconquest of space in post-1949 China. Paradoxically, both renaming processes were inspired by similar political and emotional capitals: unification, patriotism and hope for a brighter future.

Renaming implies profound inclusion and exclusion. An example of physical exclusion is the park lying at the northern tip of Shanghai's Bund (Waitan gongyuan), now known as Huangpu Park. This area, located on Chinese native soil, had become part of the British settlement (1843-63)..$^{64}$ The park 'was built on reclaimed land opposite the British Consulate and was first opened to visitors in $1868^{\prime},{ }^{65}$ but the definition of visitors or public excluded individuals of local origin. For many years, Chinese citizens were not allowed to enter this park 'except, at the discretion of the police, those who were "respectable and well-dressed" (servants

62 Carlotto was the naval lieutenant who had died in Tianjin on 15 Jun. 1901 while defending, together with a group of navy men, the so-called Italian Consulate.

63 V. Cronin, The Wise Man from the West (London, 1955).

${ }^{64}$ In 1863 the British and the American settlements were later combined in the Shanghai International Settlement (上湖公共租哭), which was administered by Shanghai Municipal

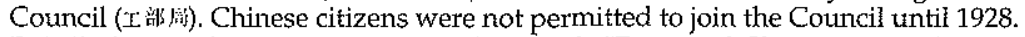

65 R.A. Bickers and J.N. Wasserstrom, 'Shanghai's "Dogs and Chinese Not Admitted" sign: legend, history and contemporary symbol', China Quarterly, 142 (1995), 445. 
of Westerners, particularly amahs, as long as they were accompanied by foreigners, and city employees, such as the Chinese police constables, were also admitted) ${ }^{\prime}{ }^{66}$ In any case, the servants of the foreign residents were not allowed to sit on the benches. ${ }^{67}$ It was only in June 1928 that the gates of this and the other parks administered by the foreign-controlled Shanghai Municipal Council of the International Settlement were finally opened also to the Chinese residents. Nevertheless, an admission charge of ten copper cents was imposed, which corresponded to half a day's average labour or more. It was only after the retrocession of the International Settlement on 1 August 1943 that the parks were opened with free entry to all the citizens. The complete reappropriation of the physical and emotional space of the Bund occurred after 1949 with the renaming of the streets. Today the Bund centres on a section of Zhongshanlu (Sun Yatsen Road), echoing the political and emotional capital of the mythical founder of the Republic.

Another example of exclusion is the foreign Legation Quarter, ${ }^{68}$ set up in Beijing as a consequence of the final Boxers' Protocol. The quarter was a separate section of the inner imperial city, lying north and inside the city walls, in the southern-Dongcheng district east of Qianmen. It included eleven foreign embassies and was exclusively reserved to the foreign powers and their citizens. It was considered foreign sovereign ground, and Chinese citizens were not allowed to take up residency within the legation grounds.

In the case of Tianjin's concessions, their openings to the Chinese dwellers hid exclusions, as demonstrated by the building codes. The rationale for exclusion reveals all the corollaries of the colonial mindset, such as the typical spirit of conquest and the associated sense of pride and progress, embodied by the agents of the mission civilisatrice, but also the affirmation of an exclusive emotional space, where enjoyment and positive feelings can only be experienced by those who are admitted into the concession and denied to the others.

\section{Sanitization and 'Italianness'}

The 1936 report produced by engineer Rinaldo Borgnino is emblematic of the narrative of benign colonialism, which dominated the fascist era. Borgnino describes the area before the Italian intervention as: miserable, noxious, desolated and sad. ${ }^{69}$ After the Italian acquisition, the hygienic modernization led to the creation of the 'aristocratic concession': a stage display of 'Italianness'. The achievements listed by Borgnino are advanced civil engineering and infrastructural projects: large roads,

${ }^{66}$ Ibid.

${ }^{67}$ For more on this theme see P. Hibbard, The Bund Shanghai: China Faces West (Hong Kong, 2007), 55-63.

${ }^{68}$ M.J. Moser and Y. Wei-chih Moser, Foreigners within the Gates: The Legations at Peking (Hong Kong and New York, 1993).

69 Borgnino, 'La "concessione", 363. 
elegant buildings, a modern hospital, the availability of electricity and drinking water in all the houses, the advanced sewage system and the public landscaping. The flagship of this laboratory of modernity ${ }^{\prime 70}$ was the first asphalt road paved in Tianjin in 1914.

Borgnino mentions a local British newspaper which defined the newly created Italian concession as 'the most pleasant residential neighbourhood among all the concessions' ${ }^{\prime}{ }^{71}$ Allegedly, the bordering concessions were stimulated to implement similar measures to improve their overall aspect, and the construct 'Italianness' became a role model worth emulating. But Borgnino's final aim is unmasked in a closing note, written by the magazine's editor who, in his address to the readers, praises Borgnino's first-hand and long-term experience in China with the syllogism: 'It is necessary to know all the assertions of the homeland, following it everywhere; and the result will certainly be an even stronger pride. ${ }^{72}$

Borgnino was pursuing his personal agenda in producing a successful image of the Italian concession, since he was the craftsman of this hygienic modernization. Supervisor of the works for the hospital's building inaugurated on 21 December 1922, following the drawings of engineer Daniele Ruffinoni - Borgnino was also in charge of the drawings of the Council headquarters. These representative buildings were meant to 'create an example, the most complete, of Italian art, a showcase of thought, technique and materials' ${ }^{73}$

In his article, Borgnino relied on the information contained in Consul Fileti's 1921 report. However, he intentionally decided to shift away from Fileti's emphasis on the economic opportunity for the Italian companies to penetrate in the Chinese 'large and virgin market', ${ }^{74}$ towards an emphasis on the buildings, since these represented national signs of distinction and prestige, and indicated the alleged success of 'Italianness'. Considering his personal involvement in the creation of the concession, his tone and selective approach are indications of a self-reflexive and self-congratulatory attitude. Borgnino's account attempted to avoid the colonial theme, and by doing so revealed the significant anxieties about Italy's imperial identity.

The Italians became, especially during the fascist period, the object of the propaganda apparatus which portrayed the concession as paradigmatic of Italian benign colonialism:

[This] small territorial entity is an eye in the faraway Orient, on which should converge both the attention of all the Italians, and the appreciative thanks for those

${ }^{70}$ I borrow this expression from Stoler, see A. Stoler, Race and Education of Desire: Foucault's History of Sexuality and the Colonial Order of Things (Durham, NC, 1995), 13-26.

71 Borgnino, 'La "concessione" was therefore a colonial rhetorical trope.

72 Ibid., 366.

73 Quoted in Cardano and Porzio (eds.), Sulla via di Tianjin, 44.

74 Fileti, La concessione, 8-9. This masculine connotation of Fileti's language seems to allude to the deflowering of China, portrayed as a feminine colonial object. 
who held high the name of the homeland. No matter what events unfold in the Chinese social or political compages, the Tien Tsin concession will remain, as Il Duce [Mussolini] defined it, an extremely advanced sentry of Italian civilization. ${ }^{75}$

'Italianness' was packaged and travelled back and forth between Italy and the imagined micro-community of the concession, in an attempt to legitimize and strengthen the collective identity of the newly formed unified Italian nation, both domestically and internationally. The Italian colonial discourse progressively discounted the Chinese internal dynamics and, in line with the fascist regime's attempt to bolster national pride, assumed strongly assertive emotional overtones tinged with greed and hunger for power.

The most evident example is offered by Ugo Bassi's 1927 lecture at the Fascist University of Bologna. First he praised the Italian soldiers who, allegedly, at the time of the repression of the Boxers' rebellion, distinguished themselves: instead of committing 'cruelties unheard of', like the soldiers of other countries, "the Italians, proud as usual of the humanist tradition of their motherland and the Roman civilization, brought to the indigenous people - where they could - aid and rescue' ${ }^{\prime 6}$ But then Bassi admitted that 'even Italy, the most civilized and famous people throughout Europe', was tempted by 'the same propulsion of greed' which characterized the other nations. ${ }^{77}$ He reiterated Fileti's argument that Italy could not miss the opportunity to mark off China 'as an actor and observer in that world where probably new global destinies were developing', and also emphasized that: 'It is not possible for an Italian to forget his Nation, unless this Italian is so degenerate to deserve the loss of his nationality as extreme punishment. ${ }^{17}$

Greed was therefore justifiable, and ultimately excused, as indicative of the same patriotic pride which was materially reflected in the built form of the concession.

\section{The former Italian concession today}

With its neo-Renaissance architecture the Italian concession symbolized an affirmation of 'Italianness', claiming a place for Italy as a nation among its peers in this miniature physical and emotional mimicry of the imperialist powers' world.

C. Cesari, La concessione Italiana di Tien-Tsin, Rome: Istituto Coloniale Fascista, 1937, n. 4, $X V, 23$. Mussolini's famous speech on Italian foreign policy at the Sernate, 5 Jun. 1928, is also quoted in Cicchitti-Suriani, 'La concessione', 565.

76 U. Bassi, Italia e Cina, 16. Bassi had previously written on the Italian colonial policy in Africa and the government of the colony in Libia. See U. Bassi, I parlamenti libici: sulla partecipazione degli indigeni al Governo della Libia (Modena, 1924); and idem, Cronache di politica coloniale (Modena, 1928). On the Italian colonial experience in Africa and in China see Del Boca, Italiani, 89-104, in particular.

78 Ibid., 22.

8 Ibid., 29. 
Since 2000, the Tianjin municipal government has started a process of renovation of the former Italian concession. The site is called Yishifengqingqu: literally meaning 'scenic area of Italian style', but usually referred to, in English, as 'Italian Business Park'. Yishifengqingqu is an Italian-flavoured, aristocratically tinged, business park with Chinese characteristics. It strives to obliterate the colonial past, and aims at marketing the former colonial buildings in order to attract foreign capital and wealthy domestic customers. ${ }^{79}$

The renamed 'area' has the function of creating a space of illusion, where the real looks unreal and the unreal conceals the real, to the extent that, in the end, one intertwines with the other, making it almost impossible to distinguish them. An example is the former S.A.I. Forum. This building, located between ex-Via Marco Polo and ex-Piazza Regina Elena, was inaugurated on 20 September 1934. A typical example of rationalistfascist architecture, it was used for sport or recreational activities, even though Chinese sources assert that it was also used for gambling. ${ }^{80}$ During a visit to Tianjin in June 2006 the whole area was under renovation: some workers argued that the original building had been torn down and completely rebuilt, while others said that its restoration had just been completed. ${ }^{81}$ Through cycles of destruction and reconstruction, old buildings are merging with the new ones creating a paradoxical effect where reality and virtual images, past and present, are so intertwined as to become surreal. Only a careful comparison of old and new maps enables one to realize how the locale still carries the burden of the historical legacy, which reflects a juxtaposition of signs belonging both to colonialism 'with Chinese characteristics' and to the nationalistic rhetoric: the central area of the concession is somehow enclosed within a perimeter delimitated by streets carrying the names of the 'three principles of the people', coined in 1924 by the 'Father of the Republic' Sun Yatsen: Minzu (Nationalism), ${ }^{82}$ Minzhu (Democracy), ${ }^{83}$ Minsheng (People's Welfare). ${ }^{84}$

Today's Yishifengqingqu is a multi-layered heterotopia of compensation, since it reveals the pretentious attempt to re-create an imaginary Italian scenery in Tianjin by showing 'a space that is other, another real space, as

79 Tianjin Yidali fenggingqu Jianzhu yu zhengxiude lishi yu huigu (Beijing, 2006).

80 Tianj̧inshi (ed.), Tianjin zujie, 262-9. After 1949 it became a cultural centre.

81 The riddie was solved in Apr. 2008 when architect Barbara Ciccolella confirmed that the building was renovated, maintaining the external appearance but radically changing the interior.

82 By which Sun meant freedom from imperialist domination.

83 Sunintended a Western constitutional government. In the Chinese case, political life should have ideally combined the power of politics (zhengquan) with the power of governance (zhiquan).

84 Minsheng can also be translated as socialism, although the government of Chiang Kai-Shek shied away from translating it as such. The concept may be understood as social welfare since Sun divided livelihood into four areas: food, clothing, housing and transportation. According to Sun, an ideal (Chinese) government should fulfil these duties for its people. Sun Yat-Sen, San Min Chu I: The Three Principles of the People, trans. F. W. Price, ed. L. T. Chen (Shanghai, 1927), 189-92, 201-2, 210-11, 262-3, 273, 278. 
perfect, as meticulous, as well arranged as ours is messy, ill constructed, and jumbled ${ }^{\prime}{ }^{85}$ This construct is in line with the civilizing discourse of the nation that, from the 1990s onwards, has characterized Chinese political rhetoric. The discourse of the strong nation, ${ }^{86}$ peacefully emerging on the world stage, has interiorized the nineteenth-century accumulative idea of 'modernity'. Tianjin (like Shanghai, Beijing, etc.) tries to sell the ex-colonial built forms for progress, obscuring other narratives of forced relocation of the tenants and expropriation of their lodgings. ${ }^{87}$

The rationale behind the creation of this new form of hybrid cityscape is the projection of a positive image, one which uses the city as a showcase of national and municipal identity. Therefore, Tianjin is re-packaging the colonial past and selling it as the beginning of its internationalization. The 'Year of Italy in China' was celebrated in 2006 and Tianjin tourist maps highlighted the 'Italian style scenic streets' (Yishifengqingjie). On the eve of the 2008 Olympics, Tianjin's taxi drivers all knew where the former Italian concession was located, primarily because the revitalization process had created a commercial area with a flavour of 'Italianness' ${ }^{88}$

\section{Distorted representations}

Today's Yishifenqingqu is not a utopian simulation of a miniature Italy; it is definitely not a mirror-image since, as Foucault suggests:

In the mirror, I see myself there where I am not, in an unreal, virtual space that opens up behind the surface; I am over there, there where I am not, a sort of shadow that gives my own visibility to myself, that enables me to see myself there where I am absent: such is the utopia of the mirror. ${ }^{89}$

Instead, what one witnesses today, walking along the streets of the former Italian concession 'area' ( $q u)$, is the result of the process of 'making new'. 133 Italian-style buildings seem to have been renovated, but many others have been demolished according to the principle pojiu lixin: 'destroy the old and erect the new'. In reality, most of the buildings dating back to the Italian concession's era have only maintained the façade. ${ }^{90}$ The result is surreal. Tianjin is often known as wanguo jianzhu bowuguan, which literally

85 Foucault, 'Des espaces autres', 48 . Foucault refers to the brothels (heterotopia of illusion) and the colonies (heterotopia of compensation) as two extreme types of heterotopia.

86 Zhao Stisheng, A Nation-State by Construction: Dynamics of Modern Chinese Nationalism (Stanford, 2004).

87 An unpublished report (3 Jun. 2006), originally prepared for China Central Television's program 'News Investigation', contains images and commentaries regarding the barbaric violence and forced relocation in the Italy scenery neighbourhood' (中国天津访河北区意式风情区野变基力挀过报告); http://house.focus.cn/msgview/ 732/53659316.html accessed on 6 Jul. 2007.

88 P. Orlandi (ed.), Urban Revitalisation in the Former European Concessions Areas in Tianjin China (Bologna, 2005).

89 Foucault, 'Des espaces autres', 47.

90 An exception are the 25 buildings renovated by the Italian company Sirena in collaboration with Tianjin City Council. 
means 'museum of architecture from a myriad of countries' ${ }^{91}$ The present pastness of Yishifengingqu reveals a hybrid between an open air museum and an open air mall: the final product has all the characteristics of a commodified space and reflects its relevant discourse of power, which is dominated by the tropes of progress, forwardness and 'newness'.

The signs naming and indicating the 'new' Italian 'area' today are christening the space, highlighting the claimed reality of reconstructed 'Italianness'. Yet, paradoxically, they are reminiscent of a historical precedent: the ubiquitous appropriation and reinvention of the urban form, and the arrogance of street signs imposed by the Italian colonial power in the period 1901-45, after the annihilation of the pre-existing 'filthy Chinese village'. ${ }^{92}$ In those days Piazza Regina Elena, Corso Vittorio Emanuele III were signs claiming 'reality' in the Italian concession, in a similar way to the signs indicating Victoria Road (today Jiefangbeilu) and Victoria Park with its Gordon Hall ${ }^{93}$ in the British concession.

A commemorative exhibition organized in December 2004 by the Italian Cultural Institute in Beijing was accompanied by the publication of a bilingual catalogue, ${ }^{94}$ whose original Italian title could be translated in English as: 'On the road to Tianjin: one thousand years of relations between Italy and China. An Italian neighbourhood in China'. The Chinese title is more concise and coincides with the subtitle of the Italian one: Yige Yidaliqu zai Tianjin (An Italian neighbourhood in China). The catalogue's cover shows Japanese children, clearly - and embarrassingly - mistaken for Chinese.

Building on the previous scholarship, the catalogue offers a good collection of photographic and archival documents relating to the Italian concession from 1902 to the 1930s. The historian, however, cannot refrain from noticing a strenuous attempt to obliterate the idea that Italy, for almost half a century, had a concession (zujie) in Tianjin, and not a 'neighbourhood'. If one could argue that the compound word zujie does not indicate a real colonial status (since 'colony' is translated in Chinese as zhimindi) or a settlement (zujiedi), nevertheless, the compound word zujie still clearly embodies the idea of 'leased territory' and includes the concept of demarcating an area where extraterritoriality was practised. ${ }^{95}$ As mentioned above, Chinese historians emphasize that the concessions were 'states within the state'. ${ }^{96}$ The linguistic replacement of 'neighbourhood' (the generic $q u$ as opposed to zujie) belongs to a typical post-colonial process of renaming and reclaiming. The modification of the form mystifies

91 Changjiu Guo (ed.), Yishijiefengqing (Italian-style scenery) (Tianjin, 2001), 1.

92 Ministero Affari Esteri, 'Concessione italiana'.

93 Built in 1889 in the northern side of the park to commemorate the British general Charles George Gordon who helped the Qing dynasty to repress the Taiping rebellion (1850-64).

${ }^{94}$ Cardano and Porzio (eds.), Sulla via di Tianjin.

95 The term $z u$ means 'to lease', jie means 'boundary', from the compound guojie, meaning boundaries of a country.

96 Shan and Liu, Tianjin, 1. 


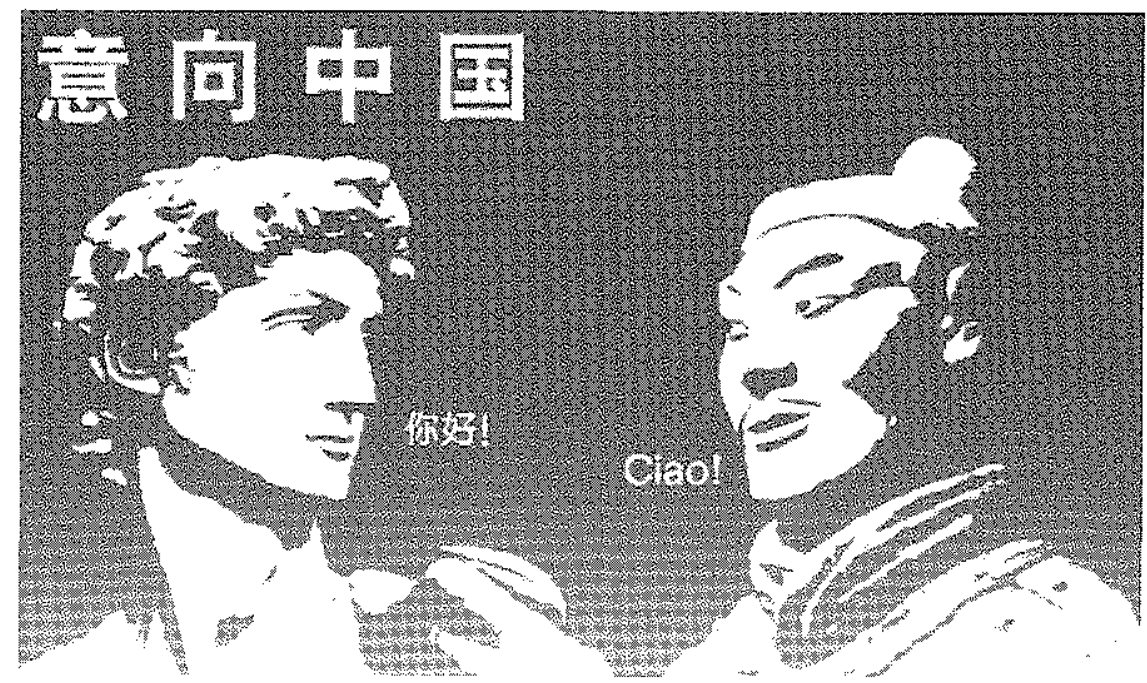

Figure 6: The logo of '2006 the Year of Italy in China' shows a juxtaposition of near and far side-by-side. The positioning of Michelangelo's David and Qin Shi Huangdi Mausoleum's Terracotta warrior appears to indicate a set of relations of space and power. Source: www.yidalinian.org retrieved 10 June 2006.

both the content and the context. This process produces an edulcorated image of the colonial presence and is an essential component of a discourse of benign colonialism, which aims at offering an over-positive and often narcissistic image of Italian colonialism. In fact $q u$, (here translated as 'neighbourhood'), literally means 'area, district, region', while the Italian term 'quartiere' conveys both the sense of a clearly defined residential district and the idea of a community characterized by some forms of vicinity or familiarity. It indicates an area whose residents share the experience of co-inhabiting a space and, at times, also certain habits, customs or emotions; they might know or somehow communicate with each other through formal or informal channels. The attempt to show that, in reality, the Italian concession was a 'neighbourhood' is dictated by the declared two-fold aim of the 2004 commemorative project: 'to encourage and expand the commercial relations between the two countries, and export and diffuse the best image of urban, architectonic, and artistic culture at that point of time to a country so faraway from Italy like China'. ${ }^{97}$ The Italian concession imagined as a 'neighbourhood' allows its representation as the witness of the implementation of a common work between Italians and Chinese that today, after more than sixty years, is somehow rediscovered and re-evaluated in its value and its 97 Cardano and Porzio (eds.), Sulla via di Tianjin, 7. 
own meaning' ${ }^{98}$ Two crucial question marks throughout the reading of the historical materials point precisely in the direction of the 'value' and 'meaning' of a possible co-operation. Today, the emphasis is placed on the 'common work of Italians and Chinese', while any signs of collaboration, interchange and hybridization are omitted from the Italian historical sources. This simulation ${ }^{99}$ process of Italianness masks the tone and the significance of the Italian colonial experience in China: it is designed to create a fictitious representation of a neighbourhood, which allegedly was 'received' from the imperial government, ${ }^{100}$ instead of being forcibly ceded as a consequence of the Boxers' final Protocol. Paradoxically (but conveniently) this approach is in line with the current Chinese official intention to represent the concessions' era as the beginning of Tianjin's internationalization, tactically capitalizing on those exuberant sprouts of global capitalism instead of demonizing them. ${ }^{101}$

\section{Conclusions}

Tianjin was one of the most politically complex treaty ports. Its hypercolonial nature was reflected in its cityscape characterized by a multilateral presence of foreign powers with their respective colonial agents. The singularity of Tianjin was determined by its multi-layered identity domestically and internationally, since multiple concessions co-existed in a single real place, and were linked globally to economic and political centres throughout Europe and Asia.

The 'production of space' 102 had physical, socio-cultural and emotive implications, and the concessions' area became a living showcase of foreign concepts of 'modernity'. The concessions' overall process of socio-spatial transformation was strictly connected to nationally connotated discourses of power, operating via mechanisms of image and knowledge construction. The representation of 'reality' was crucial in defining the transmogrifying identity of Tianjin into a hyper-colony from 1860 at least to 1928 , when Tianjin became a 'special city' under direct central control.

Forms of the past can be reinvented in the present. In the last decade, Tianjin has experienced a massive renovation programme in order to re-establish its pre-Communist era status as north China's financial capital,

98 Ibid.

99 Simulation implies the substitution 'of the signs of the real for the real itself', as Jean Baudrillard argues in his analysis of what he calls 'the precession of simulacra', where he comes to the conclusion that: 'Simulation is characterized by a precession of the model, of all models around the merest fact... Facts no longer have any trajectory of their own, they 100 arise at thid., 7.

101 See B. Sheehan, Trust in Troubled Times: Money, Banks, and State-Society Relations in Republican Tianjin (Cambridge, MA, 2003).

102 This is the title of the famous book by Henri Lefebvre, who argued that place and space do not exist sui generis but are 'produced'. H. Lefebvre, The Production of Space (New York, 1991). 
and to supplement the other dynamos of the 'Chinese miracle': Shanghai and Shenzhen. Late Socialist high-rise, shopping malls and food courts attempt to mimic the architecture of the city's imperial past. New layers of identity are being constructed and the locale of the former semi-/hypercolonial Tianjin is strategically marketed, both by the Chinese government and the foreign countries, as emblematic of the beginning of Tianjin's globalization.

The aim of this article has been two-fold: to investigate the origins of these recurrent discourses of power and to challenge them. The focus on the reinvention of the built environment in the Italian concession during the colonial period has highlighted the emotional capital, which was necessary on the one hand to sustain the Italian government's claim to legitimize the newly constructed national identity of the recently unified Italian Kingdom (1861-1946), and, on the other hand, to gain the international recognition of Italy as a legitimate imperial power.

On the level of personal narratives, the representation of the Italian concession by Consul Fileti in $1921^{103}$ reveals how the dominant story crafted by the Italian state in colonial times, through its agents, contributed to the construction of an imagined community, where the representative of the colonial state becomes the embodiment of an alleged success story for the whole nation and promotes its relevant emotional capital.

The sources analysed offer various representations of the concession, but they all share two main characteristics. First, they construct the metanarrative of the acquisition and socio-spatial reorganization of the concession as a 'laboratory of modernity'. Secondly, they emphasize the notion of shaping the Italian concession as an Italianstyle neighbourhood, a miniature Disneyland-style venue of 'Italianness', especially in terms of cultural and emotional collective capital. The projective affirmation of 'Italianness' was an integral part of colonial practices of cultural and spatial super-imposition, both in physical and emotional terms. The negotiation of national identity, combined with the international search for recognition, manifested a space in which the emotive representation of the self found unique forms of expression in the mirror of the other/s: Italian-Chinese but mainly Italian-foreign relationships. The representations proposed by Fileti, Cesari, Bassi and Pistolese all reveal a common collective emotional capital that played a crucial role in constructing the colonial regime of truth and power at the time, and still influences the Italian vision of China today. The apparently subjective and projective representations of the colonial agents ultimately unmask the emotional capital embodied by the discourse of 'Italianness'. This discourse was articulated in Tianjin through the built form imposed on the physical space, but it acted de facto as a discourse of power on two levels: first the historical nemesis of Italy in its relation to the other imperialistic 
nations and to China itself, and secondly the imaginary construction in the other space of the concession of a unitary identity for the newly formed Italian nation.

In recent years, the process of demolition, renovation and reconstruction of the buildings of the former Italian concession offers a significant example of indigenous appropriation and reinvention of emotional capital. The production of the post-colonial space and its marketization still capitalizes on the emotional appeal of a past which is fictionalized to promote 'cooperation' or, in more pragmatic terms, to attract foreign capital and launch Tianjin as a globalizing city.

The Italian concession has become today an example of hyper-heterotopia: a hyphenated space, 'something in between' ${ }^{104}$ which lives and breathes both historically and emotionally between different worlds. This area still maintains the symbolic sanitized order of colonial power but not its semantics. It is both a localized globality and a globalized locale, which disclosed the asynchronous temporalities and spatialities of past and present, thus juxtaposing global and national cultures. Paraphrasing Homi Bhabha's famous expression, it could also be defined as a 'third space': the liminal, interstitial space that exists 'between' competing cultural traditions, national boundaries, historical periods and also critical methodologies of seeing and understanding. ${ }^{105}$

Walter Benjamin, in his investigation of the reproduction of a work of art masterfully explained how its major weakness consisted in the impossibility of being present in time and space simultaneously with the original, since 'the presence of the original is the prerequisite to the concept of authenticity'. ${ }^{106}$ For the flaneur, walking today through the streets of the former Italian concession, it becomes almost impossible to discriminate between the original and the reproduction. The category of authenticity is unequivocally inadequate and perhaps commodified hybridization is the only key to perception. But this liminal, interstitial space is a place that does exist: 'a kind of effectively enacted utopia in which the real sites, all the other real sites that can be found within the culture, are simultaneously represented, contested and inverted ${ }^{107}$

104 Edward Said has explored the idea of 'in-betweenness' or living and working 'between worlds' in all his work, see E. Said, Joseph Conrad and the Fiction of Autobiography (Cambridge, MA, 1966); E. Said, E. Reflections on Exile and Other Essays (Cambridge, MA, 2002).

105 'The non-synchronous temporality of global and national cultures opens up a cultural space - a third space - where the negotiation of incommensurable differences creates a tension peculiar to borderline existences.' H. Bhabha, The Location of Culture (New York, 1994), 218, see also 102-22.

$106 \mathrm{~W}$. Benjamin, 'The work of art in the age of mechanical reproduction', in Illuminations (New York, 1968), 217-51.

107 Foucault, 'Des espaces autres', 47. 